\title{
Goose-mediated nutrient enrichment and planktonic grazer control in arctic freshwater ponds
}

\author{
G. J. Van Geest • D. O. Hessen • P. Spierenburg • \\ G. A. P. Dahl-Hansen · G. Christensen · P. J. Faerovig • \\ M. Brehm • M. J. J. E. Loonen · E. Van Donk
}

Received: 1 March 2006 / Accepted: 7 May 2007 / Published online: 3 July 2007

(C) Springer-Verlag 2007

\begin{abstract}
A dramatic increase in the breeding population of geese has occurred over the past few decades at Svalbard. This may strongly impact the fragile ecosystems of the Arctic tundra because many of the ultra-oligotrophic freshwater systems experience enrichment from goose feces. We surveyed 21 shallow tundra ponds along a gradient of nutrient enrichment based on exposure to geese. Concentrations of total phosphorus $(\mathrm{P})$ and dissolved inorganic nitrogen (DIN) in the tundra ponds ranged from $2-76$ to $2-23 \mu \mathrm{g}^{-1}$ respectively, yet there was no significant increase in phytoplankton biomass (measured as chlorophyll $a$; range: $0.6-7.3 \mu \mathrm{g}{ }^{-1}$ ) along the nutrient gradient. This lack of response may be the
\end{abstract}

Communicated by Christian Koerner.

G. J. Van Geest $(\bowtie) \cdot$ M. Brehm · E. Van Donk

Department of Food Web Studies, NIOO-KNAW,

Centre for Limnology, Rijksstraatweg 6,

3631 AC Nieuwersluis, The Netherlands

e-mail: g.vangeest@nioo.knaw.nl

\section{P. Spierenburg}

Department of Palaeo-ecology, Faculty of Biology,

University of Utrecht, Budapestlaan 4,

3584 CD Utrecht, The Netherlands

D. O. Hessen · P. J. Faerovig · E. Van Donk

Section of Marine Biology and Limnology,

Department of Biology, University of Oslo,

$\mathrm{Pb}$. 1064, Blindern, 0316 Oslo, Norway

G. A. P. Dahl-Hansen · G. Christensen

Akvaplan-niva, The Polar Environmental Centre,

9296 Troms $\varnothing$, Norway

\section{J. J. E. Loonen $(\square)$}

University of Groningen, Arctic Centre, P.O.Box 716,

9700 AS Groningen, The Netherlands

e-mail: m.j.j.e.loonen@ rug.nl result of the trophic structure of these ecosystems, which consists of only a two-trophic level food chain with high biomasses of the efficient zooplankton grazer Daphnia in the absence of fish and scarcity of invertebrate predators. Our results indicate that this may cause a highly efficient grazing control of phytoplankton in all ponds, supported by the fact that large fractions of the nutrient pools were bound in zooplankton biomass. The median percentage of Daphnia-N and Daphnia-P content to particulate (sestonic) $\mathrm{N}$ and $\mathrm{P}$ was 338 and 3009\%, respectively, which is extremely high compared to temperate lakes. Our data suggest that Daphnia in shallow arctic ponds is heavily subsidized by major inputs of energy from other food sources (bacteria, benthic biofilm), which may be crucial to the persistence of strong top-down control of pelagic algae by Daphnia.

Keywords Daphnia Plankton · Top-down control · Trophic cascades

\section{Introduction}

Over the past years, it has become evident that mobile consumers such as birds may make large contributions to rather distant ecosystems. Because waterfowl aggregate in large groups, nutrient load derived from guano may contribute up to $30-60 \%$ of nutrient loading rates in certain wetland areas (Bildstein et al. 1992; Kitchell et al. 1999; Olson et al. 2005). These bird-borne nutrients may cause eutrophication not only of wetlands but also of other ecosystems with a high density of birds.

At Svalbard, the breeding population of geese, primarily barnacle geese (Branta leucopsis Bechstein) and pink-footed geese (Anser brachyrhynchus Baillon), has increased dramatically during the last decades, partly owing to increased 
food availability at the wintering grounds but also due to climatic shifts that improve winter survival (Prop et al. 1998). These geese are impacting the surface waters of the high Arctic, which in this region mostly consist of shallow permafrost ponds in coastal areas where the birds breed and graze. The geese release fecal matter not only in the catchment of the ponds but also directly into the water, especially during moulting periods (Prop et al. 1984). This implies strong linkages between freshwater and terrestrial environments and also demonstrates that ecosystem effects at lower latitudes (i.e., increased survival of geese during the winter stay and migration) may have strong, local consequences on arctic ecosystems (Jefferies and Rockwell 2002).

The gradient in fertilization by bird-borne nutrients offers an opportunity to test the effects of nutrient input in general on these simple ecosystems, and it also allows for predictions of future effects on Arctic ponds and lakes if the expansion of geese proceeds. Arctic systems are considered to be highly sensitive to structural and functional alterations resulting from nutrient input and climate change (Hobbie et al. 1999). Arctic lakes and ponds in particular are expected to respond rapidly to changes in temperature and nutrient load because of the short (ice-free) growing season and generally nutrient-poor conditions (Douglas and Smol 1994; Rouse et al. 1997).

To predict the effects of nutrient enrichment and climate change on primary productivity, a mechanistic model needs to be developed which incorporates relevant processes for algal growth in arctic lakes and ponds (Flanagan et al. 2003). In general, algal biomass is regulated by the balance between available resources (light, nutrients, and temperature) and grazing. The relative importance of these processes in polar environments is an unresolved issue because, at similar nutrient levels, aquatic ecosystems in high-latitude regions have a lower algal biomass compared to temperate water bodies (Shortreed and Stockner 1986; Hansson 1992; Flanagan et al. 2003).

The goal of the investigation reported here was to determine the relative importance of available resources (light, temperature, and nutrients) and grazing control in a set of arctic ponds at Svalbard that formed a gradient in terms of goose exposure and, consequently, nutrient inputs. These shallow ponds on permafrost layers generally freeze solid during the winter and are thus devoid of fish. They are also characterized by high densities of the herbivorous zooplankten Daphnia, a key group for structure and functioning of many (arctic) water bodies in the northern hemisphere (Stross et al. 1980; O'Brien et al. 2004). The effects of bird-borne nutrients were determined by bioassays on limiting nutrients of phytoplankton growth and measurements of phyto- and zooplankton biomass.

\section{Materials and methods}

Study area

The 21 ponds sampled were situated on the Svalbard archipelago, Nordenskioldkysten (near Capp Linné; 14 ponds; latitude: $78^{\circ}$ ) and Kongsfjorden (near Ny-Ålesund; seven ponds; latitude: $79^{\circ}$ ). The climate in Svalbard can be characterized as an "arctic semi-desert", with short cool summers and long cold winters, and an annual precipitation of 200-300 mm. The surface area of the ponds ranged from 0.03 to 34 ha, although 19 of the 21 ponds were less than 4 ha. The sediment in the ponds consists of mud, stones, and gravel. All ponds had a high water transparency, and the bottom could be clearly seen from the water surface, allowing for a vigorous benthic production.

At both Nordenskioldkysten and Kongsfjorden, there was a gradient in nutrient levels of the ponds. The number of goose droppings at a distance up to approximately $25 \mathrm{~m}$ from the shoreline was used as an indicator of the fecal input of Barnacle geese into the ponds. The density of goose droppings in this area was recorded using a semiquantitative scale (none, low, medium, and high) and converted to an ordinal scale ranging from 0 to 3 for statistical analysis. However, such estimates only provide insight into the number of visiting geese at a relative short time scale and, in addition, a significant proportion of the goose droppings can be consumed by reindeer (van der Wal and Loonen 1998), which may strongly bias the estimates of the density of goose droppings. We therefore also estimated the cover of moss vegetation with graminoids up to a distance of approximately $25 \mathrm{~m}$ from the shoreline of the ponds, which has been shown to be positively related to the number of moulting geese near ponds in Svalbard (Prop et al. 1984; Drent et al. 1998). We estimated four classes of moss cover around the lakes: class 0: $0-10 \%$; class 1 : $11-30 \%$; class 2: $31-60 \%$, and class 3: $61-100 \%$.

Our results suggest that the nutrient gradient in the ponds may have been caused by differences in fecal input of geese. To determine the bioavailability of phosphorus $(\mathrm{P})$ in the droppings of Barnacle geese (which were collected on Svalbard and subsequently dried at $60^{\circ} \mathrm{C}$ and grounded), a bioassay with the green algae Selenastrum capricornutum was carried out in laboratory. In this bioassay, approximately $50-60 \%$ of the $\mathrm{P}$ in goose droppings was bio-available on the short term (after 11 days of incubating goose droppings at 8 and $13^{\circ} \mathrm{C}$, respectively; results not shown). For the ponds sampled, moss cover was positively related to the number of goose droppings (Spearman $R=0.47$; $P<0.05$ ), and moss cover around the lakes was positively related to particulate carbon $(\mathrm{C})$, nitrogen $(\mathrm{N})$, and $\mathrm{P}$ as well as total phosphorus (TP) levels $(R=0.47,0.44,0.64$, and 0.56 , respectively). In addition, the number of goose droppings 
was positively correlated to particulate $\mathrm{C}, \mathrm{N}$, and $\mathrm{P}$ ( $R=0.73,0.69$, and 0.53 , respectively), but not to TP $(P=0.11)$ or dissolved inorganic nitrogen (DIN) levels $(P=0.84)$. Both moss cover and number of goose droppings as well as ortho-phosphate and TP levels were higher for ponds near human settlements. This may be caused by the higher numbers of geese near ponds at these sites because in our study area geese have a strong preference to graze near human settlements (M. J. J. E. Loonen, unpublished data). Nevertheless, for ponds in the immediate vicinity of these settlements $(n=4)$ we cannot rule out additional cultural eutrophication, although three remote ponds (which were heavily influenced by geese and situated approximately $2 \mathrm{~km}$ from human settlements) also had high nutrient levels (range TP: $0.03-0.06 \mathrm{mg} \mathrm{l}^{-1}$ ). The input of feces of seabirds is assumed to be very low because the number of roosting sea birds is very low, and none of the ponds were situated in the vicinity of bird cliffs (M. J. J. E. Loonen, unpublished data). Furthermore, DIN and TP levels were not significantly related to the catchment area of the lakes (Spearman $R=-0.20$ and -0.19 , respectively). Concentrations of dissolved organic carbon (DOC) were not analyzed in this survey, but other studies in the same region show that most localities are low in DOC (1$5 \mathrm{mg} \mathrm{DOC} \mathrm{l}^{-1}$ ), and only the most eutrophied pond, which was also surrounded by wet areas and mosses, reached $10 \mathrm{mg} \mathrm{DOC}^{-1}$ (Hessen and Leu 2006).

\section{Enrichment bioassays}

The potential for phytoplankton growth limitation in two ponds in the vicinity of Ny-Ålesund was assessed using in situ nutrient-enrichment bioassays. The ponds were chosen for differences in nutrient concentrations: in Goose Pond, TP and DIN levels were 30 and $9.3 \mu \mathrm{g} 1^{-1}$, respectively; in Storvatn, they were 5 and $25 \mu \mathrm{g} 1^{-1}$, respectively. The enrichment bioassays were carried out from July 13 to 24,2004 . Water (with phytoplankton) from both ponds was collected and filtered through a $35-\mu \mathrm{m}$ sieve to remove zooplankton; this step may have potentially caused a bias in the size distribution of the phytoplankton, as chlorophyll levels for unfiltered samples at day 0 were approximately $20 \%$ higher than those for the $35-\mu \mathrm{m}$ filtered samples. Experimental bottles (acid-washed, 11, clear PVC) were filled with filtered water $(35-\mu \mathrm{m}$ sieve) collected from the respective ponds, and these were subjected to various nutrient treatments: (1) phosphate at a concentration of $50 \mu \mathrm{mol}^{-1}$, (2) $\mathrm{N}$ at a concentration of $1000 \mu \mathrm{mol} 1^{-1}$, (3) combined addition of phosphate $\left(50 \mu \mathrm{mol}^{-1}\right)$ and $\mathrm{N}$ $\left(1,000 \mu \mathrm{mol} \mathrm{l}^{-1}\right)$, and $\mathrm{N}\left(1000 \mu \mathrm{mol}{ }^{-1}\right)$ and phosphate (50 $\mu \mathrm{mol} \mathrm{l}^{-1}$ ), and (4) trace elements constituting the full COMBO medium (Kilham et al. 1998). For both ponds, each treatment was performed in triplicate. The bottles were subsequently incubated in Goose Pond at approximately $1-2 \mathrm{~cm}$ below the surface of the water for 11 days, at which time they were shaken and a subsample from each bottle filtered through a GF/C (glass fiber) filter. The filtered samples were stored at $-20^{\circ} \mathrm{C}$ until they could be analyzed for chlorophyll content (thereby excluding phaeopigments) by extraction with $80 \%$ ethanol $\left(5 \mathrm{~min}\right.$ at $\left.75^{\circ} \mathrm{C}\right)$ and spectrophotometric analysis (Anonymus 1981). Phaeopigment content was determined following acidification of the chlorophyll samples and subsequent measurement at 750 and $665 \mathrm{~nm}$.

In 2003 and 2004, 150 and 28 fresh goose droppings $(<6 \mathrm{~h})$ were collected in Ny-Ålesund on sites that were used by barnacle geese. All droppings were intensively homogenized in a blender and dried overnight in an oven at $60^{\circ} \mathrm{C}$. The dry weight of the goose droppings was then measured, and the $\mathrm{C}$, total nitrogen (TN), and TP concentrations were determined for 13 (in 2003) and five (2004) replicates. Samples for particulate (seston) $\mathrm{C}$ and $\mathrm{N}$ were ground and analyzed using an Carlo Erba Elemental Analyzer (type NA-1500). For determination of particulate P, the filters were combusted for $2 \mathrm{~h}$ at $550^{\circ} \mathrm{C}$, after which the $\mathrm{P}$ content was measured according to Murphy and Riley (1962).

Sampling of ponds

Between July 14 and August 3, 2004, 21 ponds were sampled at two areas of Svalbard - Nordenskioldkysten and Kongsfjorden. Surface water was collected at the center of each pond for all samples except those of the zooplankton (see below). The water was collected at a depth of approximately $5-10 \mathrm{~cm}$ below the surface of the water, and macrozooplankton was removed by screening the water through a $100-\mu \mathrm{m}$ Nitex mesh. The samples were subsequently analyzed for TP and chlorophyll (GF/C filters) content and following filtration through $\mathrm{GF} / \mathrm{F}$ filters - for the concentrations of dissolved nutrients $\left(\mathrm{PO}_{4}-\mathrm{P}, \mathrm{NH}_{4}^{+}, \mathrm{NO}_{3}{ }^{-}\right.$, and $\mathrm{NO}_{2}{ }^{-}$) and calcium, and salinity. All samples used for the $\mathrm{P}$ analysis were fixed with $\mathrm{H}_{2} \mathrm{SO}_{4}$, while those used for the $\mathrm{N}$, calcium and salinity analyses were stored frozen. In addition, samples (of filtered water $<100 \mu \mathrm{m}$ ) were taken for analyses of particulate $\mathrm{C}$ and $\mathrm{N}$ (GF/F filters precombusted for $2 \mathrm{~h} 500^{\circ} \mathrm{C}$ ), and particulate $\mathrm{P}$ (acid-washed $\mathrm{GF} / \mathrm{F}$ filters). Depending on the amount of algal biomass, the filtered volume for the chlorophyll $a$ and particulate CNP analyses varied between 100 and $1000 \mathrm{ml}$. Samples for the particulate $\mathrm{CN}$ analyses were dried overnight in an oven at $60^{\circ} \mathrm{C}$ and subsequently frozen at $-20^{\circ} \mathrm{C}$, while those for the chlorophyll and particulate $\mathrm{P}$ analyses were immediately frozen. For seven ponds situated at Kongsfjorden, five replicates per pond were taken for the chlorophyll and particulate CNP analyses; for the remaining 14 ponds at Nordenskioldkysten, only one replicate per pond was taken for 
each of these analyses due to logistic constraints. For two ponds located in the surroundings of Ny-Ålesund (Goose pond and Storvatn), samples were taken for the determination of chlorophyll at intervals of 1-2 days during July 2331. Data regarding the weather conditions at $\mathrm{Ny}$-Ålesund were retrieved from a meteorological station, which is situated approximately $2.5 \mathrm{~km}$ from Goose pond and Storvatn.

Samples for the particulate $\mathrm{C}$ and $\mathrm{N}$ analyses were ground and analyzed using a Carlo Erba Elemental Analyzer (type NA-1500). For the determination of particulate $\mathrm{P}$, the filters were combusted for $2 \mathrm{~h}$ at $550^{\circ} \mathrm{C}$, after which the $\mathrm{P}$ content was measured according to Murphy and Riley (1962). TP, ortho-phosphate, ammonium, nitrate and nitrite levels were measured using a segmented flow analyzer (Skalar, type SA 400). For five ponds in the surroundings of Ny-Ålesund, $100 \mathrm{ml}$ was preserved with $1 \%$ gluteraldehyde; of these samples, the total bacterial number count determined by staining with pico-green, followed by flow cytometric counting (Veldhuis et al. 1997).

Zooplankton was sampled quantitatively for 17 of the 21 ponds, and quantitative samples were taken at five to ten locations that were regularly distributed spatially in each pond. For the quantitative samples at Nordenskioldkysten, $57-1701$ of water (mean \pm SD: $66 \pm 37$ l) from each pond was filtered through a $45-\mu \mathrm{m}$ net. Zooplankton $>45 \mu \mathrm{m}$ were fixed with $80 \%$ ethanol. For Ny-Ålesund, 10-201 of water from each pond was filtered through a net and zooplankton $>45 \mu \mathrm{m}$ were subsequently fixed with lugol. The zooplankton community in the ponds was dominated by Daphnia; rotifers and copepods were recorded only occasionally. Consequently, our analysis of the length distribution, biomass, and fecundity of the zooplankton population was restricted to Daphnia species. Subsamples were taken when the number of animals exceeded 100 individuals per pond sample. Individual length (measured from top of the head to the base tail spine) was measured to the nearest $0.1 \mathrm{~mm}$, and biomass was estimated on the basis of the following length-dry weight regression $\left[\mathrm{W}(\mathrm{mg})=0.0077 \times \mathrm{L}^{2.74}(\mathrm{~mm}) ; R^{2}=0.82\right] \quad$ (Van Geest et al. 2007), which was derived from a cultivated clone of polar Daphnia pulicaria (identified according to Weider and Hobaek 2003) from Svalbard. Based on the shape of the length-frequency distribution, Daphnia biomass was calculated separately for adults and juveniles. The P content of Daphnia was then calculated using a conversion factor for P to dry weight (DW) of 1.5\% (see Hessen et al. 1992). For ten randomly collected individuals of Daphnia from each pond, the $\mathrm{C}$ and $\mathrm{N}$ content was measured after combustion at $850^{\circ} \mathrm{C}$ on a Unicarb Universal Carbon and Nitrogen Analyzer (Salonen 1979).

At Nordenskioldkysten, 23-27 individuals of Daphnia from each pond were randomly collected and stored in $80 \%$ ethanol, after which the species composition was determined according to Weider and Hobaek (2003).

\section{Results}

In situ bio-assays for nutrient limitation

We assessed nutrient limitation in the ponds based on the results of short-term bioassays of the respective phytoplankton communities (namely, allowing species composition to change during the incubation period) (Howart 1988), as limitations in the net primary production of the phytoplankton communities is indicative of nutrient limitations. The addition of all nutrients of the COMBO-medium (Kilham et al. 1998) or a combined addition of N + P stimulated algal growth, whereas separate additions of $\mathrm{N}$ or $\mathrm{P}$ did not result in increased concentrations of chlorophyll $a$ (one-way ANOVA: $P<0.000001 ; F_{4}=296$ for Storvatn; $P<0.0001 ; F_{4}=27$ for Goose pond; Fig. 1). Furthermore, in both ponds enrichment with micronutrients in addition to $\mathrm{N}$ and P resulted in significantly higher chlorophyll $a$ levels compared to $\mathrm{N}+\mathrm{P}$ addition, suggesting that in addition to $\mathrm{N}$ and $\mathrm{P}$, other nutrients may also limit algal growth.

Abiotic variables

With one exception (Ossian pool: $+92 \mathrm{~m}$ ), all ponds were situated in flat coastal lowland $\leq 30 \mathrm{~m}$ a.s.l. The surveyed ponds tended to be shallow (mean depth: $\leq 1.5 \mathrm{~m}$ ) and were
Fig. 1 Bioassay for nutrients limiting phytoplankton growth. For each pond, significant differences in chlorophyll $a$ concentrations at the end of the bioassay are indicated with different letters (post hoc comparison with Tukey HSD test, $P<0.05)$. All COMBO-medium

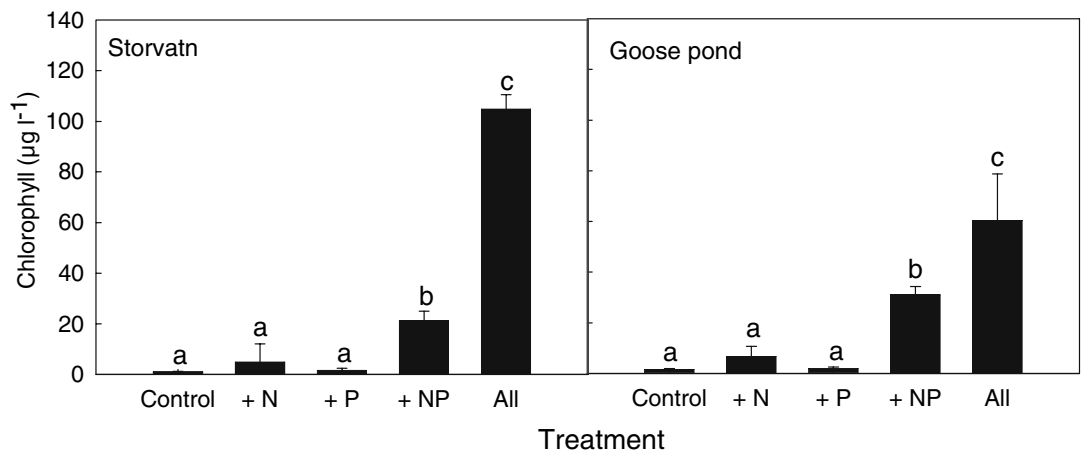


isothermal during the ice-free period (early July to late August). Water temperature of the ponds was measured during sampling (at varying times during the day) and ranged from 6 to $10^{\circ} \mathrm{C}$, but increased to $16^{\circ} \mathrm{C}$ in shallow parts of some ponds during sunny days. Hence, temperature variability within a pond at different times of the day and on different days was higher than that between ponds.

Among samples from the 21 ponds, the concentration of various elements varied considerably. TP of filtered water (TP $<100 \mu \mathrm{m}$ ) ranged from 2 to $76 \mu \mathrm{g} 1^{-1}$, and the average for all ponds was $21 \mu \mathrm{g} \mathrm{l}^{-1}$. On average, the proportion of ortho-phosphate to TP was $42 \% \pm 29$ (SE). Bio-available $\mathrm{N}$ and $\mathrm{P}$ can best be approximated measuring the levels of DIN and TP, respectively, as a large fraction of dissolved organic $\mathrm{N}$ is unavailable directly for phytoplankton growth (Morris and Lewis 1988). DIN levels ranged from 2 to $23 \mu \mathrm{g} 1^{-1}$, with an average of $8.4 \mu \mathrm{g}^{-1}$. Ammonium concentrations were all below the detection limit. Although all ponds can be characterized as fresh water, salinity (range: 0-0.529 psu) was highest in ponds situated a short distance from the sea. The nutrient content of goose droppings was comparable between years (Table 1).

\section{Bacteria and plankton composition of surveyed ponds}

Chlorophyll levels ranged from 0.6 to $7.3 \mu \mathrm{g}{ }^{-1}$ (range standard error: $0.04-0.14 \mu \mathrm{g}^{-1}$ ) and were positively related to the surface area of the pond (Spearman $R=0.66$; $P<0.01$ ). In contrast, chlorophyll levels were not significantly related to TP or DIN concentrations as determined by a multiple linear regression analysis $\left(R^{2}=0.078\right.$, $P=0.94$; Fig. 2). TP was positively related to particulate $\mathrm{C}$, $\mathrm{N}$, and $\mathrm{P}$ concentrations. The particulate $\mathrm{C}: \mathrm{P}$ ratio (molar) differed considerably among the ponds (range: 86-655), while the ratio of particulate $\mathrm{C}: \mathrm{N}$ ranged from 7 to 14 . The particulate N:P ratio ranged from 7 to 70 , whereas the N:P ratio of goose feces ranged from 6 to 9 (Table 1). For two ponds in the vicinity of Ny-Ålesund, chlorophyll concentrations (range: $0.3-2.8 \mu \mathrm{g}^{-1}$ ) were positively related to daily variations in wind speed (Fig. 3), which indicates the resuspension of benthic autotrophs into the water column during windy periods. Bacterial counts ranged from $6.6 \times 10^{6}$ to $3.8 \times 10^{7}$ and were strongly positively correlated to TP

Table 1 Carbon (C), nitrogen (N), and phosphorus (P) content of freshly collected goose droppings of barnacle geese (Branta leucopsis) in 2003 and 2004

\begin{tabular}{lllllll}
\hline 1 & $\mathrm{C}$ & $\mathrm{N}$ & $\mathrm{P}$ & $\mathrm{C}: \mathrm{N}$ & $\mathrm{C}: \mathrm{P}$ & $\mathrm{N}: \mathrm{P}$ \\
\hline 2003 & $441 \pm 2$ & $11 \pm 2.5$ & $3.9 \pm 0.13$ & 47 & 292 & 6.2 \\
2004 & $460 \pm 5$ & $11 \pm 1.5$ & $2.7 \pm 0.29$ & 49 & 440 & 9.0
\end{tabular}

Concentrations are given in milligrams per gram dry mass; ratios are expressed on a molar basis

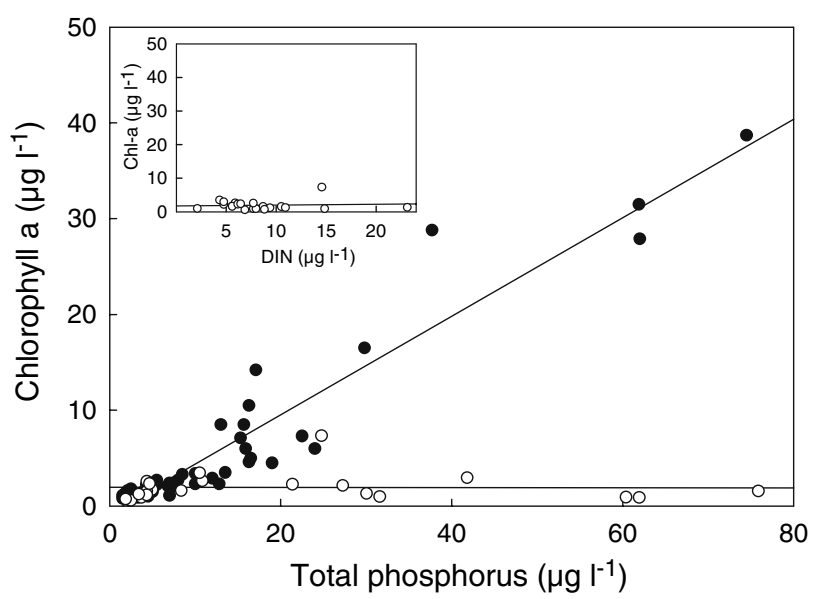

Fig. 2 Relationship between chlorophyll $a\left(\mu \mathrm{g}^{-1}\right)$, total phosphorus (TP; $\mu \mathrm{g}^{-1}$ ), and dissolved inorganic nitrogen (DIN; $\mu \mathrm{g}^{-1}$ ) in arctic Svalbard ponds (open circles; fish absent) and subarctic Norwegian lakes and ponds (closed circles; fish present)

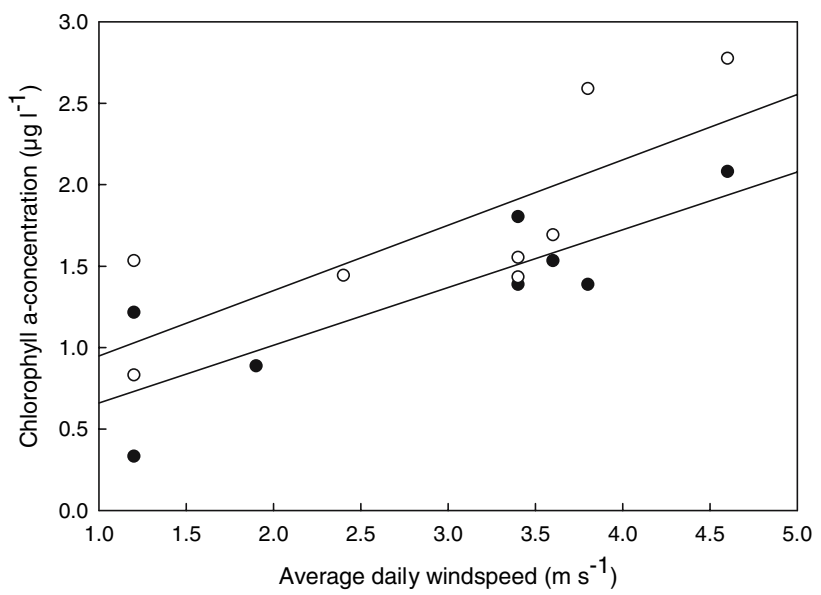

Fig. 3 Relationship between average daily wind speed $\left(\mathrm{m} \mathrm{s}^{-1}\right)$ and chlorophyll concentration $\left(\mu \mathrm{g}^{-1}\right)$ in the Storvatn (open circles) and Goose ponda (closed circles) in July 2005. The meteorological station was situated approximately $2.5 \mathrm{~km}$ from both ponds

content of the ponds (Product Moment Correlation $=0.98$; $P<0.05 ; n=5$ ).

Based on the bimodal length frequency distribution of the Daphnia population, two separate cohorts of Daphnia could be distinguished in each pond: one represented individuals that had hatched from ephippia shortly after the iceoff, and a second cohort of (juvenile) individuals consisted of offspring from the first generation (Fig. 4). The total biomass of Daphnia was negatively correlated with the particulate C:P ratio (Fig. 5; Spearman $R=-0.72$ ), while particulate $\mathrm{P}$ was marginally related to total Daphnia biomass $(R=0.42 ; P=0.09)$. Total Daphnia biomass was not related to the particulate $\mathrm{C}: \mathrm{N}$ ratio nor to chlorophylla levels in the ponds. The biomass of juvenile Daphnia's was positively related to particulate $\mathrm{C}, \mathrm{N}$ or $\mathrm{P}(R=0.63,0.56$, and 0.74 , respectively), but not to the particulate $\mathrm{C}: \mathrm{P}$ or $\mathrm{C}: \mathrm{N}$ 


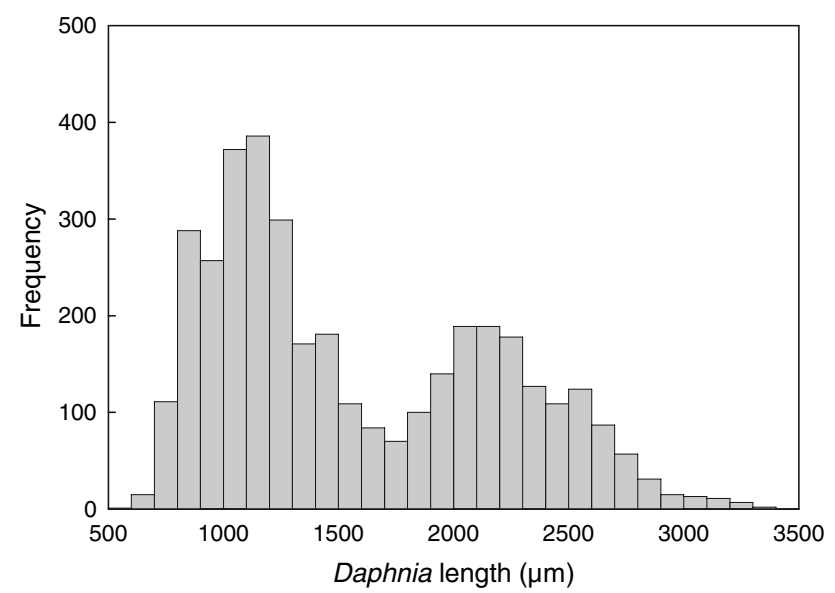

Fig. 4 Histogram of Daphnia length in all sampled ponds $(n=21)$. Note the bimodal frequency distribution, representing one cohort of adults and one cohort of juveniles, respectively

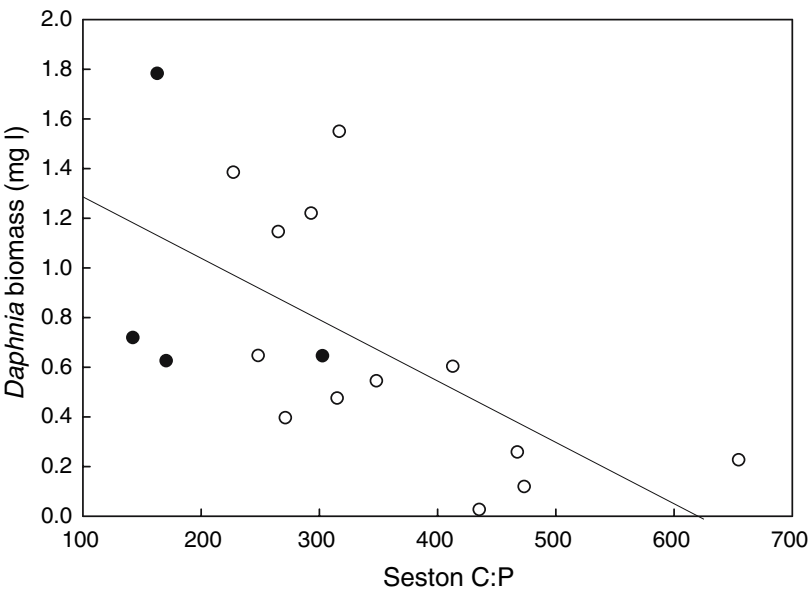

Fig. 5 Relationship between the particulate (seston) C:P ratio (molar) and Daphnia biomass (mg DW $1^{-1}$ ) for ponds at Kongsfjorden (closed circles) and Nordenskioldkysten (open circles). Data for Daphnia biomass were available for 17 of the 21 ponds

ratios. The presence of the notostracan Lepidurus arcticus Pallas was recorded in four of the 21 ponds and was not related to Daphnia biomass or nutrient content of the ponds.

At the time of sampling, reproduction was almost entirely restricted to adult Daphnia, as $<1 \%$ of the second cohort of Daphnia carried eggs or ephippia. The prevalence of ephippia varied between 0 and $46 \%$ of the adult population in the ponds and was not related to TP content or other (a)biotic variables. In contrast, egg-bearing Daphnia were only present in ponds with low TP (and hence high particulate C:P). For the ponds at Nordenskioldkysten $(n=14)$, the Daphnia community consisted of D. tenebrosa and polar $D$. pulicaria, and - in one pond - European D. pulicaria (Tables 2, 3).

The median percentage of Daphnia- $\mathrm{N}$ and Daphnia-P content relative to particulate (seston) $\mathrm{N}$ and $\mathrm{P}$ was 338 $(\mathrm{w} / \mathrm{w})$ and $3009 \%$, respectively. This indicates that other sources of $\mathrm{P}$ than seston must be available to Daphnia (bacteria, benthic biofilm).

\section{Discussion}

A major finding in this study was the lack of a positive correlation between concentrations of chlorophyll and TP or DIN, supporting previous studies in arctic water bodies (Flanagan et al. 2003). It has been suggested that in the arctic, phytoplankton may not be able to utilize increased nutrient levels because of the limitations set by low water temperatures (Flanagan et al. 2003) or low photosynthetic rates (Markager et al. 1999). However, chlorophyll levels increased rapidly in the in situ bio-assay enrichments in our ponds, indicating that algal growth rates were not suppressed by low water temperature or physiological constraints. This can be explained by the shallowness of these ponds, which warm up faster and hence have an extended growing season with higher temperatures compared to (generally deeper) arctic lakes (Miller et al. 1980).

Our results suggest that the striking lack of correlation between nutrient levels and chlorophyll may be partly explained by the "two-level" food web structure of arctic ponds (see Hansson 1992). In our ponds, Daphnia biomass

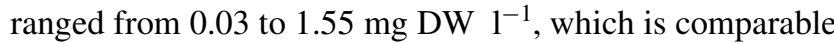
with observations elsewhere in shallow arctic ponds (Stross et al. 1980) and fishless alpine ponds (Strecker et al. 2004). The strong increase in Daphnia biomass with the decreasing C:P ratio of seston (namely, increasing $\mathrm{P}$ content) suggests that increased nutrient loadings were directly channeled into grazer biomass in these systems. Tundra ponds freeze solid during winter and are thus devoid of fish, while the omnivorous invertebrate Lepidurus arcticus, which was present in some ponds, was seemingly unable to control zooplankton biomass despite its potential to utilize Daphnia as a potential food source (Christoffersen 2001). Hence, top-down control on grazers was virtually absent, which allowed for a high Daphnia biomass and a truly efficient grazing in these ponds (see Hessen et al. 2004). As a result, primary production was efficiently channeled into Daphnia without causing elevated algal biomass.

In addition to zooplankton grazing, the lack of a correlation between TP and algal biomass may also be caused by $\mathrm{N}$ limitation setting constraints on algal growth in arctic lakes and ponds (Levine and Whalen 2001; Nydick et al. 2004) or a narrower range of bio-available $P$ than indicated by the TP values [E. Jeppesen (unpublished) in Vadeboncoeur et al. 2003]. However, TP values were highly correlated to particulate $\mathrm{P}$ and $\mathrm{N}$ concentrations, indicating that a substantial fraction of the $\mathrm{N}$ and $\mathrm{P}$ was available for algal growth. In addition, DIN levels were not related to chlorophyll 


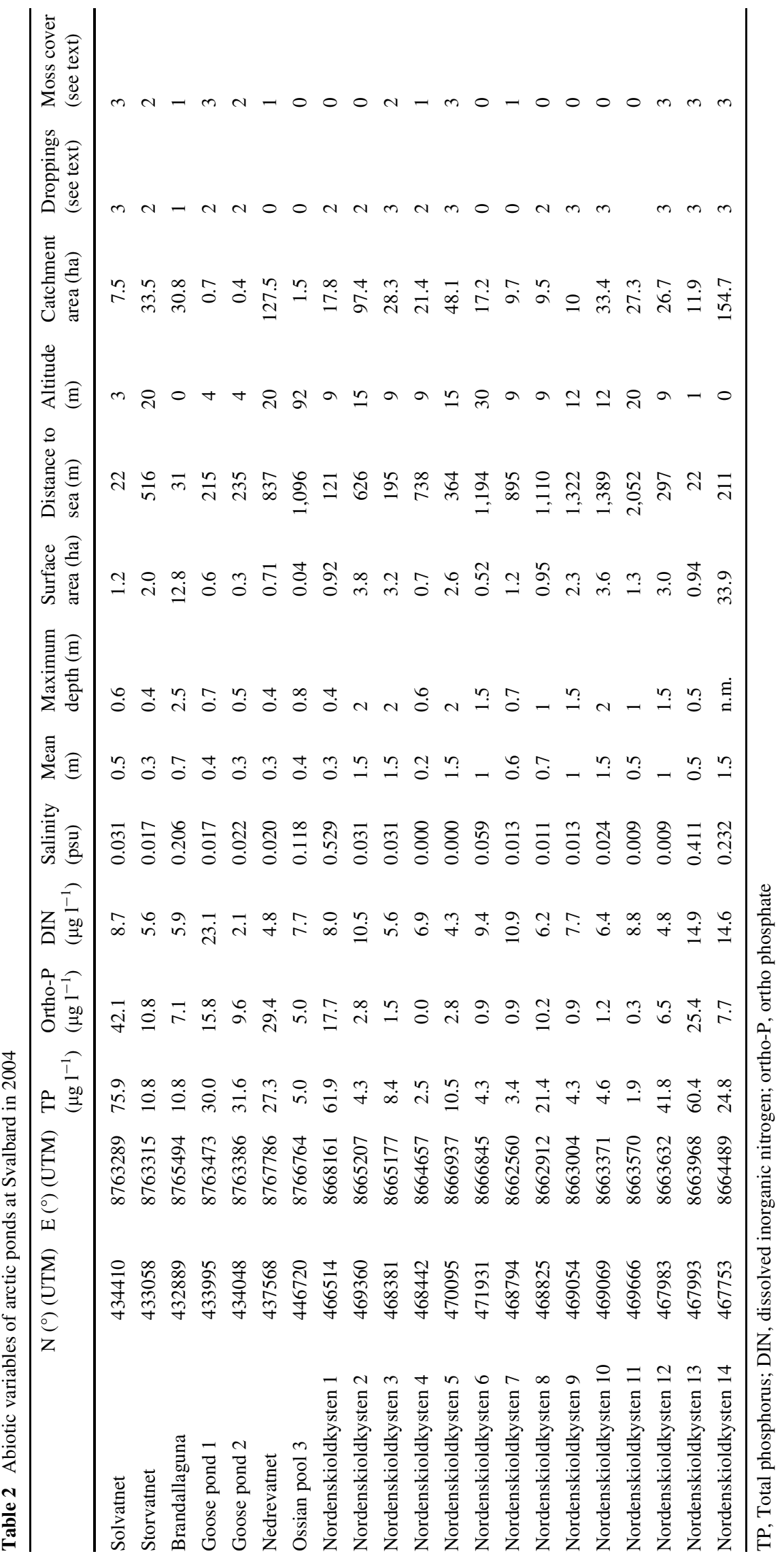




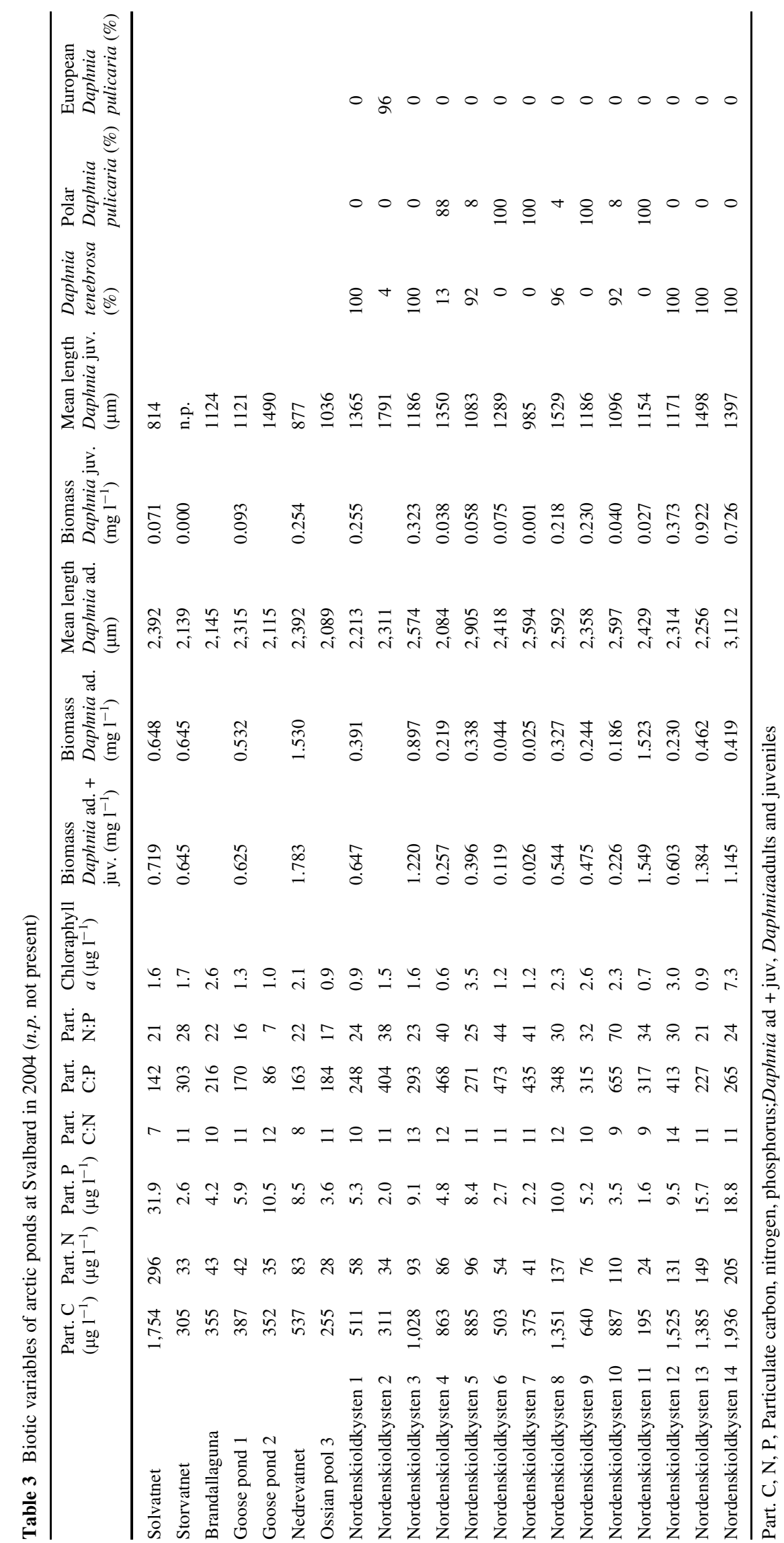


concentrations during multiple regression. Nevertheless, based on the concurrent limitation of algal growth by $\mathrm{N}+\mathrm{P}$ in the bioassays, we cannot exclude the possibility that, in addition to intense zooplankton grazing, $\mathrm{N}$ limitation of phytoplankton growth may also partly explain the lack of correlation between TP and algal biomass. In agreement with our results, Levine and Whalen (2001) also suggested $\mathrm{N}$ and NP levels limited phytoplankton production in 39 Alaskan lakes. However, the strong stimulation of algal biomass by addition of micronutrients in the bioassays suggests that these elements may also limit phytoplankton growth. In these shallow ponds with high water transparency, phytoplankton may experience nutrient competitions from benthic algae (Hansson 1988), and the relationship between chlorophyll and nutrient concentrations may be affected by the resuspension of benthic algae on windy days. In two ponds sampled repetitively, chlorophyll varied from $0.3 \mu \mathrm{g} \mathrm{l}^{-1}$ on quiet days up to $2.7 \mu \mathrm{gl}^{-1}$ on windy days. However, although these factors may have influenced the nutrient-to-chlorophyll ratio in our survey, the striking difference between these arctic fishless systems and subarctic Norwegian lakes with fish (Fig. 2) suggest a strong grazing control by zooplankton in the absence of fish.

The molar C:P ratio of seston was far higher than 300 even in the most nutrient-poor ponds, which is the threshold ratio above which Daphnia growth becomes P-limited (Sterner 1993). Accordingly, the C:P ratio of seston increased with decreasing $\mathrm{P}$ levels and coincided with a strong decrease in Daphnia biomass. Bacterial numbers as well as the particulate $\mathrm{C}: \mathrm{P}$ ratio were highly positive related to the concentrations of TP in the ponds (Product Moment $R^{2}=0.98 ; n=5$ ). Therefore, in nutrient-rich ponds, bacteria could serve as an important alternative P source for Daphnia, as bacteria are relative rich in $\mathrm{P}$ (Hessen and Andersen 1990; Vadstein 2000). A similar increase in Daphnia density and bacterial number with TP has also been found in sub-arctic water bodies (Shortreed and Stockner 1986).

The positive relation between chlorophyll and average wind speed (Fig. 3) or lake surface area suggests that in our shallow wind-exposed ponds, a large proportion of algae in the water column may very well have a benthic origin. These results suggest that Daphnia's in shallow arctic ponds are heavily subsidized by major inputs of energy from benthic food sources, as has experimentally been demonstrated in other arctic water bodies (Rautio and Vincent 2006). Indeed, mass balance studies of C fluxes in a mesocosm experiment in Brandallaguna (a pond which is included in our survey) showed that the pelagic algal and bacterial production was insufficient for sustaining the maintenance costs of Daphnia during zooplankton peak biomass (Hessen et al. 2004). The role of this "subsidizing" energy link between benthic algae and daphnids may be crucial to the persistence of high Daphnia biomass and, consequently, a persistent strong top-down control of phytoplankton.

Compared to temperate lakes, the percentage of $\mathrm{N}$ and $\mathrm{P}$ bound in Daphnia biomass is extremely high (median of $3009 \%$ for $\mathrm{P}$ and $338 \%$ for $\mathrm{N}$ compared to maximum values of approximately 50 and $20 \%$, respectively, for oligotrophic temperate lakes; Hessen et al. 1992). Consequently, in these systems Daphnia's do not only recycle nutrients but also serve as temporary nutrient traps. This may have strong implications in terms of the nutrient limitation of phytoplankton growth, as indicated by the concurrent limitation of $\mathrm{N}$ and $\mathrm{P}$ in the bioassays. Concurrent limitation by $\mathrm{N}$ and $\mathrm{P}$ may be indicative of an extreme shortage of these nutrients for phytoplankton growth (Morris and Lewis 1988). As a result, cellular N:P ratios are near limiting values for a large proportion of the phytoplankton assemblage, and even a small increase in $\mathrm{P}$ concentration may drive algae growth into a $\mathrm{N}$ limitation state or, vice versa, cause a situation rather close to co-limitation of $\mathrm{N}$ and $\mathrm{P}$. Thus, as a consequence of Daphnia-dominance in these "two-level" food web systems, we hypothesize that pelagic algae suffer directly from grazing and indirectly from reduced nutrient availability due to the accumulation of nutrients in the form of Daphnia biomass.

The increased geese population in the high Arctic constitutes an important link between climate changes and land-use practices in central Europe and affects remote and fragile ecosystems in the high Arctic. In terms of its effects on freshwater ecosystems, however, although it may indeed affect benthic productivity, our results indicate that nutrient enrichment in fishless ponds may not necessarily result in increased algal biomass due to intense zooplankton grazing, thereby supporting the view that the number of trophic levels is vital to trophic cascade effects.

Acknowledgements This study was carried out within the framework of the FRAGILE-project (Fragility of Arctic Goose Habitat: Impacts of Land Use, Conservation and Elevated Temperature) and was financed by the EU.

\section{References}

Anonymus (1981) Water-spectrophotometric determination of chlorophyll-a content; NEN 6520. Netherlands Institute for Standardization, Delft

Bildstein KL, Blood E, Frederick P (1992) The relative importance of biotic and abiotic vectors in nutrient transport. Estuaries 15:147157

Christoffersen K (2001) Predation on Daphnia pulex by Lepidurus arcticus. Hydrobiologia 442:223-229

Douglas MSV, Smol JP (1994) Limnology of high arctic ponds (Cape Herschel, Ellesmere Island, NWT). Arch Hydrobiol 131:401-434

Drent RH, Black JM, Loonen MJJE, Prop J (1998) Barnacle geese Branta leucopsis on Nordenskiöldkysten, western Spitsbergen in thirty years from colonization to saturation. In: Mehlum F, 
Black JM, Madsen J (eds) Research on arctic geese. Proc Svalbard Goose Symp. Norsk Polarinstitutt Skrifter 200

Flanagan KM, McCauley E, Wrona F, Prowse T (2003) Climate change: the potential for latitudinal effects on algal biomass in aquatic ecosystems. Can J Fish Aquat Sci 60:635-639

Hansson LA (1988) Effects of competitive interactions on the biomass development of planktonic and periphytic algae in lakes. Limnol Oceanogr 33:121-128

Hansson LA (1992) The role of food-chain composition and nutrient availability in shaping algal biomass development. Ecology 73:241-247

Hessen DO, Andersen T (1990) Bacteria as a source of phosphorus for zooplankton. Hydrobiologia 206:217-223

Hessen DO, Leu E (2006) Trophic transfer and trophic modification of fatty acids in high Arctic lakes. Freshw Biol 51:1987-1998

Hessen DO, Andersen T, Faafeng B (1992) Zooplankton contribution to particulate phosphorus and nitrogen in lakes. J Plankton Res 14:937-947

Hessen DO, Blomqvist P, Dahl-Hansen G, Drakare S, Lindstrom ES (2004) Production and food web interactions of Arctic freshwater plankton and responses to increased DOC. Arch Hydrobiol 159:289-307

Hobbie JE, Peterson BJ, Bettez N, Deegan L, O’Brien WJ, Kling GW, Kipphut GW, Bowden WB, Hershey AE (1999) Impact of global change on the biogeochemistry and ecology of an Arctic freshwater system. Polar Res 18:207-214

Howart RW (1988) Nutrient limitation of net primary production in marine ecosystems. Annu Rev Ecol Syst 19:89-110

Jefferies RL, Rockwell RF (2002) Foraging geese, vegetation loss and soil degradation in an Arctic salt marsh. Appl Veg Sci 5:7-16

Kilham SS, Kreeger DA, Lynn SG, Goulden CE, Herrera L (1998) COMBO: a defined freshwater culture medium for algae and zooplankton. Hydrobiologia 377:147-159

Kitchell JF, Schindler DE, Herwig BR, Post DM, Olson MH, Oldham M (1999) Nutrient cycling at the landscape scale: the role of diel foraging migrations by geese at the Bosque del Apache National Wildlife Refuge, New Mexico. Limnol Oceanogr 44:828-836

Levine MA, Whalen SC (2001) Nutrient limitation of phytoplankton production in Alaskan Arctic foothill lakes. Hydrobiologia 455:189-201

Markager S, Vincent WF, Tang EPY (1999) Carbon fixation by phytoplankton in high Arctic lakes: implications of low temperature for photosynthesis. Limnol Oceanogr 44:597-607

Miller MC, Prentki RT, Barsdate RJ (1980) Physics. In: Hobbie JE (ed) Limnology of tundra ponds, Barrow, Alaska. Dowden, Hutchinson \& Ross, Stroudsburg, pp 51-75

Morris DP, Lewis WM (1988) Phytoplankton nutrient limitation in Colorado Mountain Lakes. Freshw Biol 20:315-327

Murphy J, Riley JP (1962) A modified single solution method for determination of phosphate in natural waters. Anal Chim Acta 26:31-36

Nydick KR, Lafrancois BM, Baron JS, Johnson BM (2004) Nitrogen regulation of algal biomass, productivity, and composition in shallow mountain lakes, Snowy Range, Wyoming, USA. Can J Fish Aquat Sci 61:1256-1268
O'Brien WJ, Barfield M, Bettez ND, Gettel GM, Hershey AE, McDonald ME, Miller MC, Mooers H, Pastor J, Richards C, Schuldt J (2004) Physical, chemical, and biotic effects on arctic zooplankton communities and diversity. Limnol Oceanogr 49:1250-1261

Olson MH, Hage MM, Binkley MD, Binder JR (2005) Impact of migratory snow geese on nitrogen and phosphorus dynamics in a freshwater reservoir. Freshw Biol 50:882-890

Prop J, van Eerden MR, Drent RH (1984) Reproductive success of the Barnacle Goose Branta leucopsis in relation to food exploitation on the breeding grounds, western Spitsbergen. Nor Polarinst Skr 181:87-117

Prop J, Black JM, Shimmings P, Owen M (1998) The spring range of barnacle geese Branta leucopsis in relation to changes in land management and climate. Biol Conserv 86:339-346

Rautio M, Vincent WF (2006) Benthic and pelagic food resources for zooplankton in shallow high-latitude lakes and ponds. Freshw Biol 51:1038-1052

Rouse WR, Douglas MSV, Hecky RE, Hershey AE, Kling GW, Lesack L, Marsh P, McDonald M, Nicholson BJ, Roulet NT, Smol JP (1997) Effects of climate change on the freshwaters of arctic and subarctic North America. Hydrol Process 11:873-902

Salonen K (1979) A versatile method for the rapid and accurate determination of carbon by high temperature combustion. Limnol Oceanogr 24:177-183

Shortreed KS, Stockner JG (1986) Trophic status of 19 Sub-Arctic Lakes in the Yukon Territory. Can J Fish Aquat Sci 43:797-805

Sterner RW (1993) Daphnia growth on varying quality of Scenedesmus: Mineral limitation of zooplankton. Ecology 74:2351-2360

Strecker AL, Cobb TP, Vinebrooke RD (2004) Effects of experimental greenhouse warming on phytoplankton and zooplankton communities in fishless alpine ponds. Limnol Oceanogr 49:1182-1190

Stross RG, Miller MC, Daley RJ (1980) Zooplankton. In: Hobbie JE (ed) Limnology of tundra ponds, Barrow, Alaska. Dowden, Hutchinson \& Ross, Stroudsburg, pp 251-296

Vadeboncoeur Y, Jeppesen E, Vander Zanden MJ, Schierup HH, Christoffersen K, Lodge DM (2003) From Greenland to green lakes: cultural eutrophication and the loss of benthic pathways in lakes. Limnol Oceanogr 48:1408-1418

Vadstein O (2000) Heterotrophic, planktonic bacteria and cycling of phosphorus-Phosphorus requirements, competitive ability, and food web interactions. In: Schink B (ed) Advances in microbial ecology, vol. 16. Springer, Berlin Heidelberg New York, pp 115167

Van Geest GJ, Spierenburg P, Van Donk E, Hessen DO (2007) Daphnia growth rates in Arctic ponds: limitation by nutrients or carbon? Pol Biol 30:235-242

van der Wal R, Loonen MJJE (1998) Goose droppings as food for reindeer. Can J Zool Rev Can Zool 76:1117-1122

Veldhuis MJW, Cucci TL, Sieracki ME (1997) Cellular DNA content of marine phytoplankton using two new fluorochromes: taxonomic and ecological implications. J Phycol 33:527-541

Weider LJ, Hobaek A (2003) Glacial refugia, haplotype distributions, and clonal richness of the Daphnia pulex complex in arctic Canada. Mol Ecol 12:463-473 